\title{
Ramularia collo-cygni-An Emerging Pathogen of Barley Crops
}

\author{
Neil D. Havis, James K. M. Brown, Gladys Clemente, Peter Frei, Malgorzata Jedryczka, Joanna Kaczmarek, \\ Maciej Kaczmarek, Pavel Matusinsky, Graham R. D. McGrann, Sylvia Pereyra, Marta Piotrowska, \\ Hind Sghyer, Aurelien Tellier, and Michael Hess
}

First, seventh, ninth, and eleventh authors: Crop and Soil Systems Research Group, Scotland's Rural College, West Mains Road, Edinburgh, Scotland, UK; second author: John Innes Centre, Norwich Research Park, Norwich, UK; third author: Patología Vegetal, FCA (UNMdP), Unidad Integrada Balcarce, Ruta $226 \mathrm{Km}$ 76,3, 7620, Balcarce, Buenos Aires, Argentina; fourth author: Agroscope, Institute of Plant Production Sciences, Nyon, Switzerland; fifth and sixth authors: Institute of Plant Genetics, Polish Academy of Sciences, Poznan, Poland; eighth author: Agrotest fyto, Ltd., Kromeriz, Czech Republic; tenth author: INIA-National Institute for Agricultural Research, La Estanzuela, Ruta 50 km 11, 70000, Colonia, Uruguay; twelfth and fourteenth authors: Phytopathology, TUM School of Life Sciences, Weihenstephan, Technische Universität München, Germany; thirteenth author: Population Genetics, TUM School of Life Sciences, Weihenstephan, Technische Universität München, Germany.

Accepted for publication 16 January 2015.

\begin{abstract}
Havis, N. D., Brown, J. K. M., Clemente, G., Frei, P., Jedryczka, M., Kaczmarek, J., Kaczmarek, M., Matusinsky, P., McGrann, G. R. D., Pereyra, S., Piotrowska, M., Sghyer, H., Tellier, A., and Hess, M. 2015. Ramularia collo-cygni-An emerging pathogen of barley crops. Phytopathology 105:895-904.

Ramularia collo-cygni is the biotic factor responsible for the disease Ramularia leaf spot (RLS) of barley (Hordeum vulgare). Despite having been described over 100 years ago and being considered a minor

disease in some countries, the fungus is attracting interest in the scientific community as a result of the increasing number of recorded economically damaging disease epidemics. New reports of disease spread and fungal identification using molecular diagnostics have helped redefine RLS as a global disease. This review describes recent developments in our understanding of the biology and epidemiology of the fungus, outlines advances made in the field of the genetics of both the fungus and host, and summarizes the control strategies currently available.
\end{abstract}

Symptoms of Ramularia leaf spot (RLS) were first reported more than 100 years ago in Italy (Cavara 1893). The agent associated with the disease was initially described as the fungal pathogen Ophiocladium hordei but has since been renamed as Ramularia collo-cygni (Sutton and Waller 1988). The disease occurs late in the season, inducing rectangular reddish-brown necrotic spots that are visible on both sides of the leaf blade (Fig. 1), usually surrounded by a chlorotic halo (Salamati and Reitan 2006) and premature leaf senescence, leading to loss of green leaf area in crops and subsequent yield reductions. Despite the presence of RLS since the late $1800 \mathrm{~s}, R$. collo-cygni has only been recognized as an important pathogen of barley in the last 30 years. The lack of recognition may have been due to the confusion of RLS with physiological leaf spots, other diseases, and rapid crop senescence.

There is a strong link between the environmental factors which induce the production of physiological leaf spots and the activation of the anthraquinone toxin, rubellin, which is produced by the fungus. Rubellins have been characterized as nonhost-specific toxins inducing photodynamic necrosis of leaf tissue (Miethbauer et al. 2003). The potential role of rubellin in RLS epidemiology of disease has been reviewed elsewhere (Walters et al. 2008) and is the subject of ongoing studies and, therefore, will not be discussed further in this review. RLS began to attract serious attention in the 1980s, when the economic importance of the disease was first appreciated. The development of molecular diagnostics (Frei et al. 2007; Havis et al. 2006; Taylor et al. 2010) has improved detection of $R$. collo-cygni and has enabled RLS to be easily distinguished from other barley diseases (e.g., Pyrenophora teres f. maculata,

Corresponding author: N. D. Havis; E-mail address: Neil.Havis@ sruc.ac.uk

http://dx.doi.org/10.1094/PHYTO-11-14-0337-FI

(C) 2015 The American Phytopathological Society senescing Blumeria graminis lesions, and physiological leaf spotting) in the field. In fact, RLS has now been reported all over the temperate world from New Zealand to South America and Canada to Europe. Advances in disease diagnostics have also allowed the quantification of fungal infection in seed from across Europe and South America, providing further insights into potential modes of transmission of this disease (Havis et al. 2014a), whereas examination of archived seed material from various countries has demonstrated an increase in $R$. collo-cygni levels over the last 30 years. The emergence of RLS as an important disease of barley has led to renewed research efforts to improve the basic knowledge of the pathogen and its distribution, epidemiology, and methods for disease control. In the past 12 years, RLS has been the subject of three sessions at the International Barley Leaf Blight Workshops, two satellite meetings at International conferences, and two dedicated European conferences. The findings of studies presented there and in literature that approach the important questions still outstanding about this recently established disease are reviewed here.

\section{GEOGRAPHIC DISTRIBUTION}

RLS had been reported across Europe, including in Scotland, England, Ireland, France, Denmark, Germany, Austria, the Czech Republic, and Switzerland, as well as in Chile, Mexico, Columbia, the United States, and New Zealand (Walters et al. 2008). In more recent years, RLS has been identified in crops and seed samples from the Slovak Republic, Estonia, Russia, Iceland, Poland, and Spain (Afanasenko et al. 2012; Gubiš et al. 2008; Koric et al. 2009, Sooväli et al. 2014) (N. Havis and M. Jedryczka, unpublished data). The fungus has also been detected in seed samples from one site in Israel and at very low levels from Namibia (M. Hess, unpublished data).). Although, in many cases, diagnosis of RLS presence has 
been based on accurate identification of the characteristic fungal structures and disease symptoms (Carmona et al. 2013; Khier et al. 2002; Stewart 2001) the use of molecular diagnostic tools has shown that $R$. collo-cygni is present in seed samples and is spreading in crops, sometimes without causing severe epidemics (Clemente et al. 2014; Pereyra 2013).

Outside Europe, RLS has emerged as a serious threat to barley production in South America (Fig. 2). The initial description of RLS in Argentina was restricted to the typical barley-growing area of the southwest of Buenos Aires province and was associated with $100 \%$ foliar incidence and symptom severity of 60 to $100 \%$ (Khier et al. 2002). One decade later, in 2012, RLS was detected in barley crops at the north of the Pampas region, in Entre Ríos,

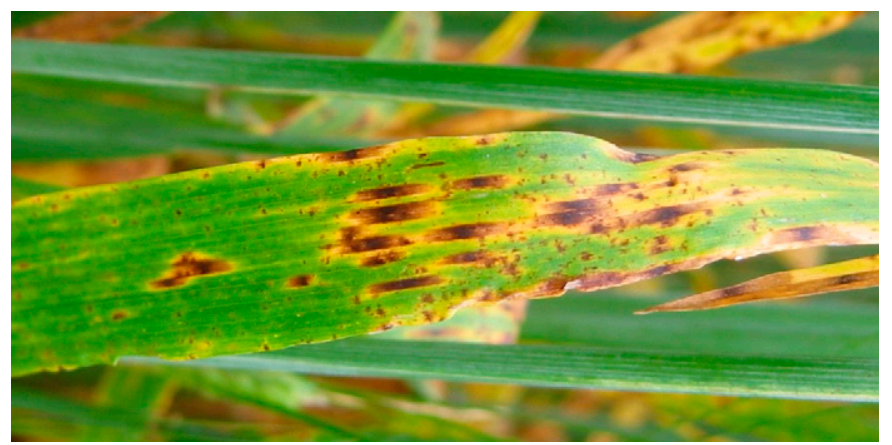

Fig. 1. Ramularia leaf spot symptoms in barley (Hordeum vulgare). south of Santa Fe, north and southeast of Buenos Aires, causing premature reductions of leaf green area and related yield losses (Carmona et al. 2013; Clemente et al. 2014; Havis et al. 2014a). In Uruguay, RLS has been a sporadic disease in the past but its occurrence has increased in the last decade and, since 2011, it has become a major constraint to barley production. Reductions in grain yield of up to $70 \%$ have been estimated in susceptible varieties during the epidemic years, while the fraction of grains greater than $2.5 \mathrm{~mm}$ was reduced by $90 \%$ (Pereyra 2013). These findings, in conjunction with data from other countries, show that RLS causes losses of both quantity and quality in barley crops.

Improved education on the identification of RLS combined with molecular diagnostic assays has undoubtedly aided the diagnosis of RLS from other spotting diseases and disorders of barley globally. Evidence from molecular detection in seed samples collected from around the world indicates that the fungus is very widespread within barley-growing regions worldwide, even where disease levels are low. The importance of seed-borne long-distance dispersal remains an open question of immediate relevance to better understand the global spread and reemergence of this disease.

\section{EPIDEMIOLOGY}

Recent studies in barley have improved the understanding of the relationship between the $R$. collo-cygni and seed of the host while highlighting the potential importance of a secondary spore type in the fungal life cycle. Confirmation of a seed-borne stage in the fungal life cycle (Havis et al. 2006) has led to a better understanding of the biology of R. collo-cygni and of disease spread at a field and

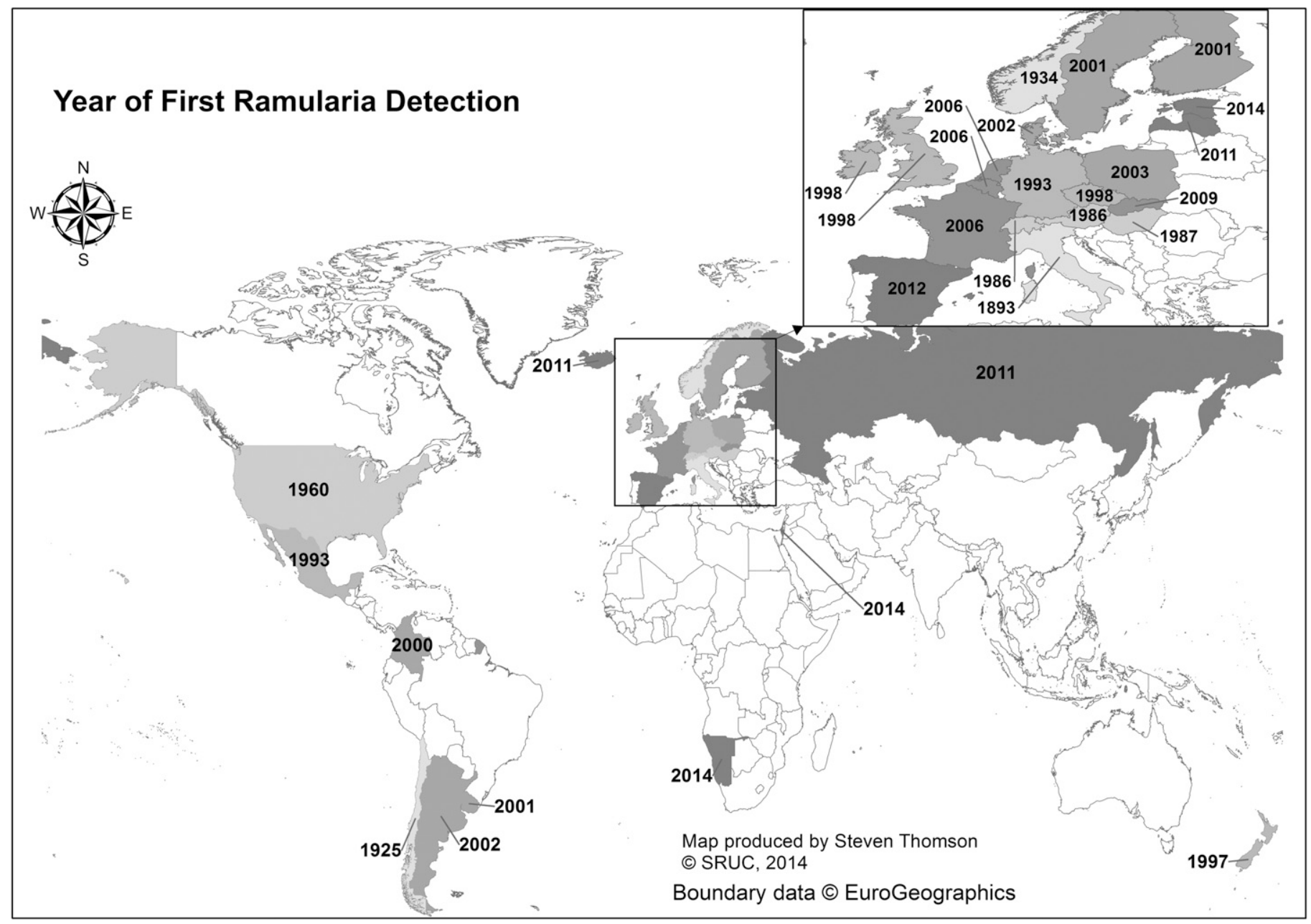

Fig. 2. Current recorded distribution of Ramularia collo-cygni (Ramularia leaf spot symptoms or fungal DNA), with year of initial report. 
global scale. Testing of seed archives in the United Kingdom and Germany indicated that $R$. collo-cygni was present in the United Kingdom prior to the first botanical description in Italy (Fountaine and Fraaije 2009) and that fungal DNA levels have been increasing since the beginning of the 21 st century. $R$. collo-cygni has been consistently detectable in Germany since the 1960s but significant increase in DNA levels was observed two decades earlier than in the United Kingdom, in the 1980s (Table 1). The cause of this rapid increase in $R$. collo-cygni detection has not been fully established and remains a question of utmost importance to determine why RLS has emerged as a threat to barley production.

Detection of $R$. collo-cygni in barley seed was also confirmed by Matusinsky et al. (2011) and Kaczmarek et al. (2013). Careful dissection of harvested seed from the Czech Republic into its component parts combined with quantitative polymerase chain reaction (qPCR) analysis revealed that $R$. collo-cygni was present in the covering layers of the seed and the lemma, and occurred in lower amounts in the pericarp and embryo. No DNA was detected in the endosperm, although it should be noted that seed infection levels were low in the study by Matusinsky et al. (2011) compared with those recorded in the United Kingdom, South America, and Bavaria (Clemente et al. 2014; Havis et al. 2009b, 2014a; Hess et al. 2014; Oxley and Havis 2010). Whole-plant inoculation studies with a green fluorescing protein (GFP)-transformed isolate developed by Thirugnanasambandam et al. (2011) showed $R$. collo-cygni accumulation under the seed coat outside the aleurone layer and the GFP signal in all seed component parts, including the endosperm (Kaczmarek et al. 2013). It is likely that the difference in the reported location of $R$. collo-cygni with seed from these two studies can be explained by variation in seed-borne infection levels observed in naturally infected seed compared with those from artificially inoculated plants.

A number of studies have shown that $R$. collo-cygni moves from infected seed into developing plant tissue in both controlled environments and the field, confirming the vertical transmission of the fungus (Havis et al. 2014c; Nyman et al. 2009; Zamani-Noor et al. 2009). Zamani-Noor et al. (2009) tested seed harvested from a severely infected barley field in Germany and found a high incidence of asymptomatic infection. Seed were grown in controlled conditions in the absence of external inoculum and the fungus was detected in emerging leaf layers. Nyman et al. (2009) found similar results but also showed that the combination of seed infection plus external inoculation produced higher $R$. collo-cygni DNA levels in planta compared with plants grown from infected seed without subsequent inoculation, or artificially inoculated plants grown from $R$. collo-cygni-free seed. Havis et al. (2014c) studied the growth of $R$. collo-cygni from infected seed in field conditions. The presence or absence of external inoculum was monitored by the use of continuous spore trapping and qPCR. R. collo-cygni DNA was tracked up the crop canopy in the absence of external spore movement, indicating that epidemics in the United Kingdom develop from seed-borne infection and that late-season spore movement does not influence disease epidemics (Fig. 3). Schützendübel et al. (2008) found a closer relationship between spore movement and disease epidemics in trials in Germany and supported the original life cycle of $R$. collo-cygni, which suggested a role for spore movement in disease epidemiology supported by a green bridge between winter and spring crops (Sachs 2006). Zamani-Noor (2011) found that spore release from winter crops contributed to disease levels in spring crops. Ongoing testing of spore samples from Poland has shown R. collo-cygni DNA present between April and June in both 2013 and 2014 (J. Kaczmarek, unpublished data). Spore testing in the United Kingdom and Poland has shown that $R$. collo-cygni DNA can be detected in areas where symptoms are rarely seen (N. Havis and M Jedryczka, unpublished data).

In addition to airborne spores, Salamati and Reitan (2006) demonstrated the development of a secondary spore type for $R$. collo-cygni, described as an Asteromella stage. These structures have also been reported from in vitro cultures and on barley straw
(Kaczmarek et al. 2013; Khier et al. 2002). The function of these structures has not been fully established, although it has been suggested that this could be the site of sexual recombination in the fungus (Kaczmarek et al. 2013). Identification of the sexual stage of the fungus will greatly assist with the classification of this organism.

Although primarily a pathogen of barley, $R$. collo-cygni has been reported to cause disease on other cereals and grasses. In Switzerland, R. collo-cygni was isolated from Hordeum vulgare L., Triticum aestivum L., T. durum Dest., Avena sativa L., Poa pratensis L., Lolium perenne L., and Agropyron repens (L.) Beauv. (Frei and Gindrat 2000). Peraldi et al. (2014) showed that the fungus can infect the model plant Brachypodium distachyon. $R$. collo-cygni can also infect seed of different grasses, suggesting that vertical transmission is possible in a number of grass species (N. Havis, unpublished data). What role these alternative hosts play in the epidemiology of RLS remains undetermined.

Prediction and control of RLS epidemics has been problematic. Occasional symptoms and sporulation have been seen on plants during vegetative growth on senescent leaves or in stressed crops

TABLE 1. Detection of Ramularia collo-cygni DNA in barley seed archives from Germany ${ }^{z}$

\begin{tabular}{|c|c|}
\hline Location, year & R. collo-cygni detection \\
\hline \multicolumn{2}{|l|}{ Germany } \\
\hline \multicolumn{2}{|l|}{ Winter barley } \\
\hline 1958-64 & + \\
\hline 1965 & + \\
\hline $1966-67$ & + \\
\hline 1968 & ++ \\
\hline 1969 & nt \\
\hline $1970-75$ & + \\
\hline 1976 & $\mathrm{nt}$ \\
\hline 1977 & ++ \\
\hline $1978-87$ & + \\
\hline 1988 & ++ \\
\hline 1989 & ++ \\
\hline 1990 & ++ \\
\hline 1991 & + \\
\hline 1992 & + \\
\hline 1993 & + \\
\hline 1994 & ++ \\
\hline 1995 & ++ \\
\hline 1996-2000 & ++ \\
\hline 2001-04 & ++ \\
\hline 2005 & - \\
\hline $2006-$ & - \\
\hline 2007 & ++ \\
\hline \multicolumn{2}{|l|}{ Spring barley } \\
\hline $1958-64$ & $\mathrm{nt}$ \\
\hline 1965 & + \\
\hline $1966-67$ & + \\
\hline 1968 & + \\
\hline 1969 & + \\
\hline 1970 & + \\
\hline 1976 & + \\
\hline 1977 & + \\
\hline $1978-87$ & + \\
\hline 1988 & + \\
\hline 1989 & ++ \\
\hline 1990 & + \\
\hline 1991 & + \\
\hline 1992 & ++ \\
\hline 1993 & + \\
\hline 1994 & + \\
\hline 1995 & ++ \\
\hline 1996-2000 & + \\
\hline 2001-04 & - \\
\hline 2005 & + \\
\hline $2006-$ & + \\
\hline 2007 & - \\
\hline
\end{tabular}

${ }^{\mathrm{z}}$ Symbols: $\mathrm{nt}=$ none tested $-=$ no $R$. collo-cygni DNA detected, $+=<1 \mathrm{pg}$ of $R$. collo-cygni DNA per $100 \mathrm{ng}$ of DNA, and $++=>1 \mathrm{pg}$ of $R$. collo-cygni DNA per 100 ng of DNA. 
(Havis et al. 2014b; Hess et al. 2007; Huss 2002; Pereyra 2013) but the vast majority of symptoms appear post flowering; that is, from Zadoks growth stage (ZGS) 70 (Zadoks et al. 1974) onward in the crop. Identification of the disease at this growth stage is too late for fungicide application to control RLS. Results from qPCR analysis of $R$. collo-cygni DNA levels from spore tapes and meteorological data from a site in Scotland highlighted a significant correlation between prolonged levels of leaf surface wetness in July and spore dispersal (Havis et al. 2009b). An increase in spore release was also observed when ambient temperature increased from 5 to $15^{\circ} \mathrm{C}$, indicating temperature as a factor for this process. This has been observed with other fungi (Toscano-Underwood et al. 2001) In other studies, a high humidity level was found to be crucial for the outbreak of RLS epidemics, while radiation intensity was of minor importance (Formayer et al. 2004). Marik et al. (2011) found that stronger symptomatic expression was positively affected by a higher number of rainy days in the 3 weeks post heading. These authors also reported that higher temperatures and lower rainfall post flowering reduced disease levels in the Czech Republic.

Salamati and Reitan (2006) reported a positive correlation between relative humidity in early June, corresponding to ZGS 30/31 (stem extension) in the crop, in mid-Norway, and RLS disease levels in spring barley crops. This correlation between high levels of relative humidity and increased RLS symptom expression has also been observed in recent years in Norway (J.-E. Kvam-Andersen, personal communication). A similar relationship between leaf surface wetness at ZGS 30/31 and RLS severity in winter and spring barley crops was observed in Scotland, suggesting an important role for leaf surface wetness at this growth stage in RLS epidemiology (Havis et al. 2012). Research is ongoing to use this information to develop a wider forecast system for RLS epidemics in the United Kingdom and Germany.

The environment clearly has an important role in the expression of RLS symptoms. Variation in disease symptom expression has been demonstrated in field trials. Havis et al. (2009b) suggested that differences in symptom expression in 16 spring barley varieties sown at five different sites within Scotland were primarily caused by the different environmental conditions experienced by the crop at each site. Exposure to high light levels prior to inoculation increased RLS symptoms in different barley varieties and in
B. distachyon under controlled conditions, further indicating the relationship between environmental conditions and disease expression (Makepeace et al. 2008; Peraldi et al. 2014). The current understanding of the $R$. collo-cygni life cycle is summarized in Figure 4.

Vertical transmission of the fungus between host generations has been demonstrated for $R$. collo-cygni and barley and also for wheat and other grasses (N. Havis, unpublished data). The relationship between the environment and disease expression is being slowly elucidated and there is emerging evidence that the fungus has an endophytic stage in its life cycle (Newton et al. 2010). However, further research is needed to fully explain the life cycle of the fungus.

\section{CONTROL OF RLS}

The average yield benefit from RLS control has been reported from various sources to be in the region of $0.4 \mathrm{t} / \mathrm{ha}$ in Europe (Hess et al. 2007; Walters et al. 2008) but can vary by region and variety (Hess et al. 2011; Oxley and Havis 2009). South American grain yield losses as high as $70 \%$ have been estimated during epidemic years in susceptible cultivars. These losses were associated with a $90 \%$ reduction in yield of grains $>2.5 \mathrm{~mm}$ in size (Clemente et al. 2014; Pereyra 2013). RLS not only reduces grain yield but also negatively affects grading and malt quality (Hess et al. 2011; Pinnschmidt and Jørgensen 2009). Pinnschmidt and Jørgensen (2009) attributed the yield loss from RLS to a reduction in 1,000grain weight in infected plots.

Control of RLS has generally been reliant on the use of fungicides (Hess et al. 2007, 2009; Walters et al. 2008). Research from Croatia has suggested that removing infected volunteer barley plants is an effective cultural control technique (Koric et al. 2009). However, this is not always practical in continuous cereal production systems.

Strobilurin-based fungicides (quinone outside inhibitors [QoI]) initially provided one of the best chemical solutions for managing RLS but loss of sensitivity quickly developed and spread in many countries. QoIs, which inhibit the cytochrome bc1 complex of the respiratory chain, are an important group of chemical fungicides, active against a broad spectrum of fungal diseases (Bartlett et al. 2002). Resistance to QoI appeared in the major wheat pathogen

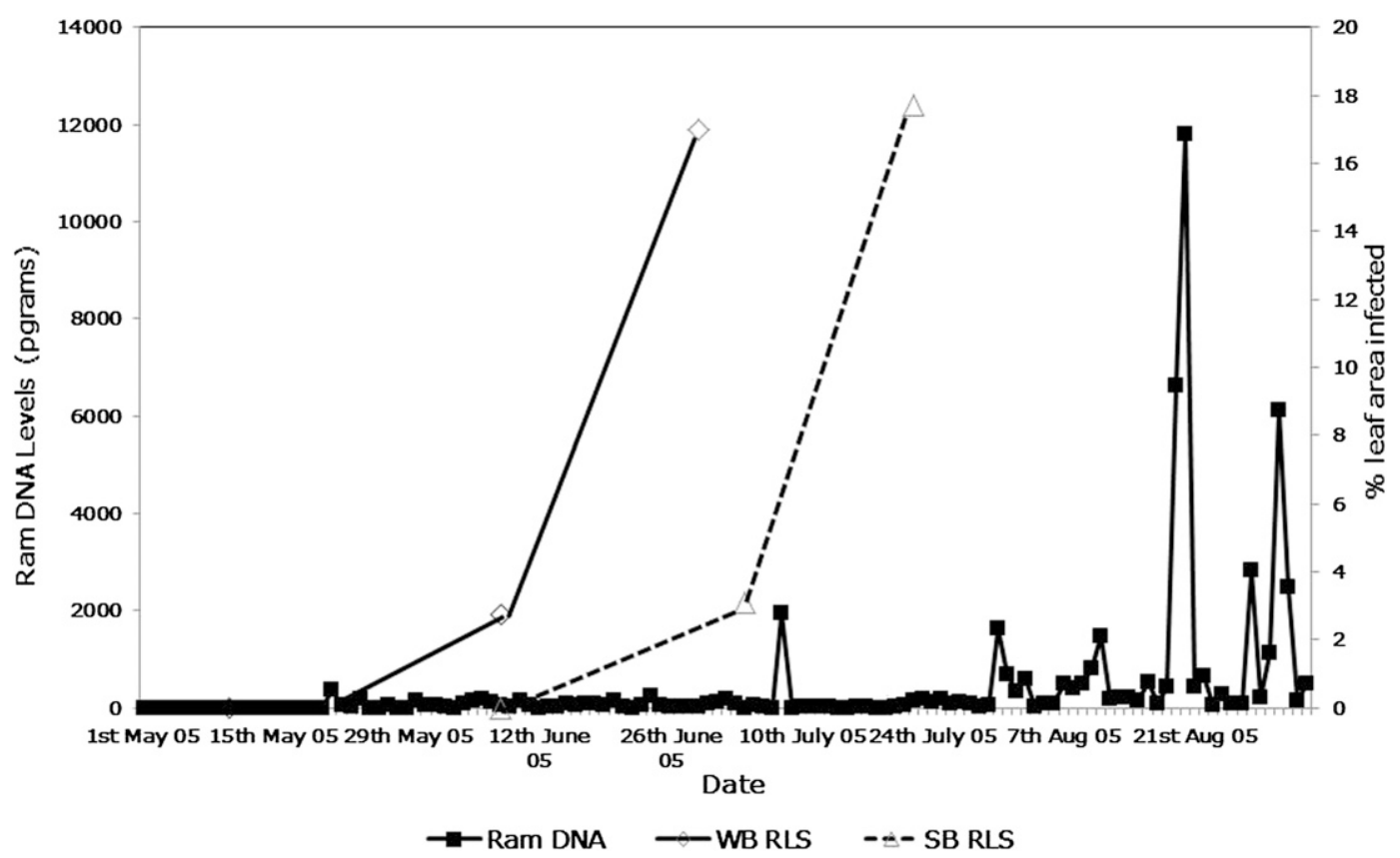

Fig. 3. Ramularia collo-cygni DNA levels from daily spore tape extract versus Ramularia leaf spot (RLS) symptom expression, Bush Estate, Midlothian, Scotland 2005. 
Mycosphaerella graminicola in the early years of the century (Fraaije et al. 2005). Fountaine and Fraaije (2009) found that the rapid decline in efficacy of QoI fungicides for RLS control in the United Kingdom is the result of the G143 point mutation in the cytochrome $b$ gene which is now prevalent in $R$. collo-cygni populations. The authors showed that, in DNA from the isolates collected from Scotland and Denmark in 2007, only the mutated DNA sequence was present. In the study of Matusinsky et al. (2010), 302 isolates of $R$. collo-cygni were collected in 2009 from 12 locations in the Czech Republic and the resistant allele was detected in $47 \%$ of the isolates. The frequency of the G143A mutation per location depended on the frequency of application of strobilurin fungicides against leaf diseases of barley. Because the first registration for RLS control in Germany for a QoI mix product was in 2006, it is likely that $R$. collo-cygni became resistant to the QoI component prior to this date (Table 2). In Norway, where the use of strobilurins was more carefully regulated, the proportion of sensitive to resistant alleles remains closer to 50:50 (J.-E. Kam-Anderson, personal communication). The continued use of strobilurins in RLS control programs in Argentina and Uruguay suggests that they are still effective. Indeed, field trials in Uruguay showed that azoxystrobin in combination with chlorothalonil gave increased control of RLS compared with chlorothalonil alone, which could only partly be explained by effects on pathogens and plant physiology (Pereyra et al. 2014).

Currently, chemical control of RLS relies on using products with different modes of action (FRAC 2014). The first products to be registered were based on prothioconazole (demethylation inhibitor $[\mathrm{DMI}]$ ) and chlorothalonil (Ctl) (multisite), followed by boscalid (succinate dehydrogenase inhibitor [SDHI]) (according to the recommendations list of the Bavarian State Research center provided by S. Weigand, Fresing, Germany). The introduction of a new generation of SDHI (bixafen, fluxapyroxad, and isopyrazam) (Table 2) has given barley growers a significant boost in their options to control pathogens (Russell 2009). However, there are concerns surrounding stewardship of SDHI and, because $R$. collo-cygni is capable of relatively rapid resistance build up (Fountaine and Fraaije 2009; Matusinsky et al. 2010), guidelines for their use have been produced (FRAC 2014).

In the United Kingdom, $R$. collo-cygni was recently reclassified as a major pathogen (Havis et al. 2010), making fungicide and variety trials for RLS control an obligatory part of barley disease management recommendations. Fungicide performance is tested on an annual basis and data made available to growers (HGCA 2014) In other countries, the situation is less clear, partly due to the confusion of RLS with other disease symptoms (Walters et al. 2008) and the strong association with abiotic spotting (Frei and Gindrat 2000). Many products are registered as having activity against both (Table 2). Nevertheless, as a consequence of its increasing economic importance, products to control RLS are now in the majority for commercially approved fungicides (Table 2). In Switzerland, the multisite targeting chlorothalonil is the backbone of RLS treatments, usually in combination with an SDHI or demethylation inhibitor (P. Frei, personal communication).

Fungicide timing plays an important role in the efficacy of sprays. Trials in Uruguay show that the greatest control of RLS was achieved by a three-spray program (applications at ZGS 33, 38, and 47) (Pereyra et al. 2014) (Table 3). However, this is not always practical or economic in many countries. The best control from a two-spray program involved treatments at ZGS $33+$ ZGS 47
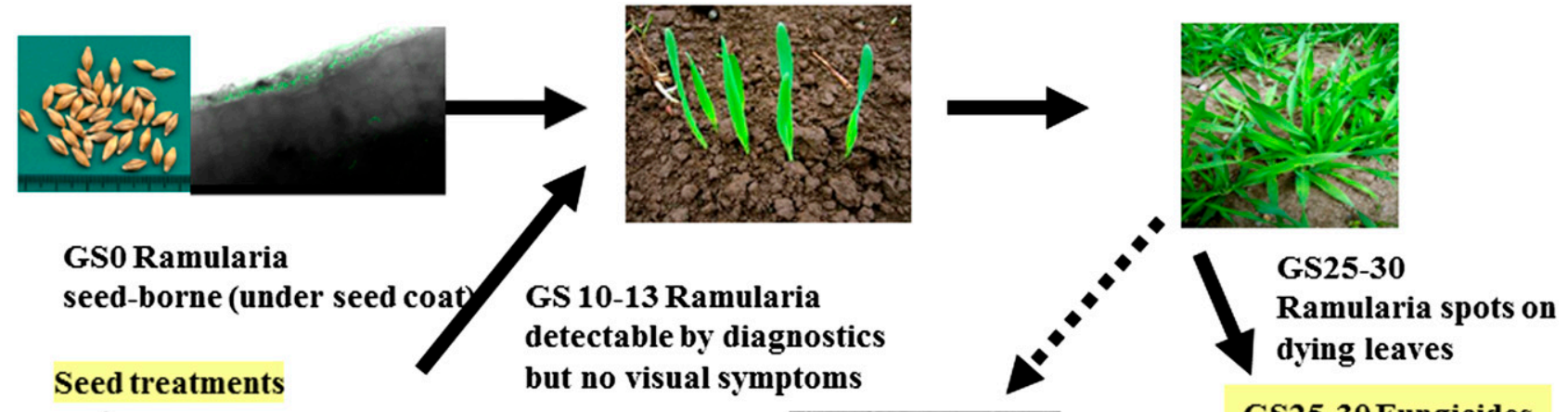

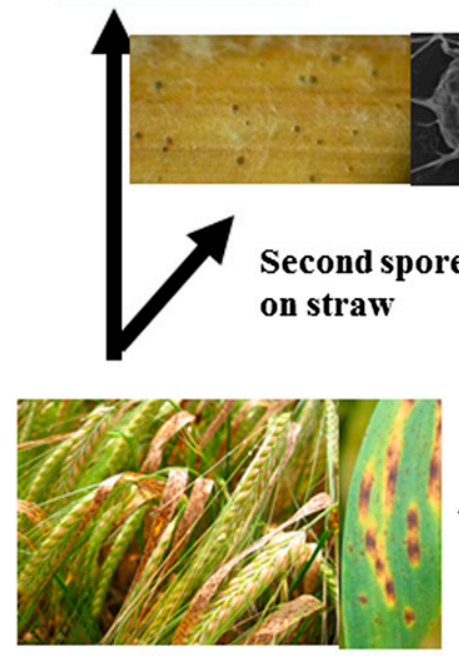

GS72-85Ramularia symptoms on leaves, heads and awns
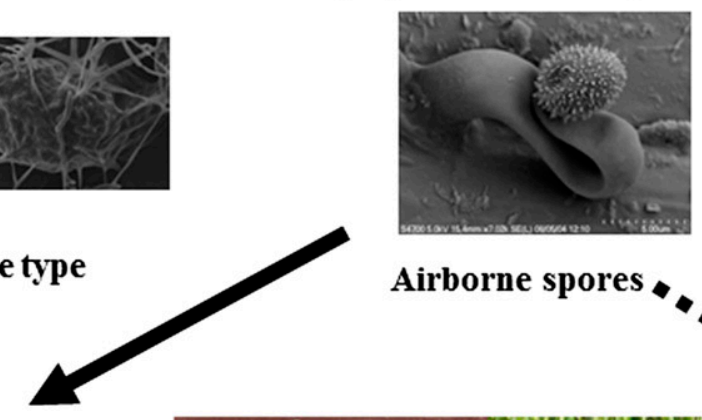

Airborne spores
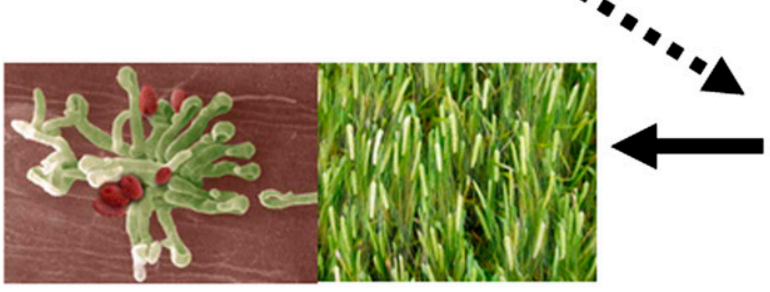

Fig. 4. Life cycle of Ramularia collo-cygni in barley (Hordeum vulgare).

\section{GS65 Fungus detected inside leaves 2-4 weeks before symptoms}

GS45-49

Protect crops

with fungicide
GS25-30 Fungicides can reduce later disease epidemic

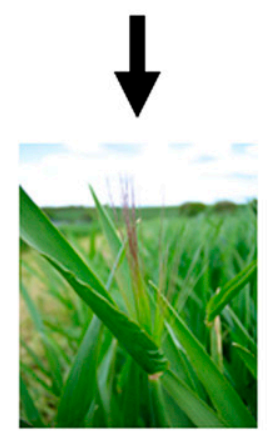


(Table 3). Timing of the application plays an important role for efficiency and most studies have shown best effects for late treatments at awn peeping (ZGS 49). Reports from Argentinian commercial trials indicated that the best disease control could be achieved by mixtures of strobilurins, DMI, and SDHI applied at early stem elongation (ZGS 32). Erreguerena et al. (2014) determined a protection window for barley against RLS by the application of an azoxystrobin + isopyrazam mixture between barley stem elongation (ZGS 30) and first awns visible (ZGS 49). The ZGS 49 treatment has also been recommended for RLS control in Switzerland (P. Frei, personal communication), Germany (Hess et al. 2007), and the United Kingdom (Havis et al. 2012). However, the choice and timing of fungicides in a growing season will depend on disease incidence and severity in the crop (Hess et al. 2014).

Defense elicitors have also been tested against RLS (Walters et al. 2008). These compounds prime the defense response in the host plant and offer the prospect of broad-spectrum disease control by utilizing the plant's natural defense mechanisms. Results from a number of trials suggest that these compounds may not have a role to play as a solo treatment but did give significant reductions in RLS when applied early (ZGS 24), followed by reduced-rate fungicides at ZGS 31 and ZGS 39 (Havis et al. 2009a). However, other trials using a combination of elicitors that activate different defense pathways demonstrated a negative effect on RLS control compared with other pathogens (Walters et al. 2012). Although there is potential for using elicitors as part of an integrated control strategy for RLS, the reported trade-off between elicitor combinations and RLS highlights that further research is required before these compounds can be recommended for commercial use.

The control of $R$. collo-cygni by seed treatments has been examined in a number of countries. Research in Scotland showed that commercial seed treatments based on triazoxide and tebuconazole could reduce RLS in susceptible varieties (Havis et al. 2010). However, this effect was not seen in every season. Analysis of $R$. collo-cygni DNA showed that these chemicals also had little effect on fungal movement in barley (Havis et al. 2010). The effect of hot-water treatments on fungal DNA levels has been studied in a number of laboratories. This treatment has been shown to reduce $R$. collo-cygni DNA levels (Havis et al. 2010) but avoiding damage to the embryo has proved very difficult (Zamani-Noor 2011). Two biological seed treatments and a steam seed treatment were also tested (Havis et al. 2010) but no consistent control of RLS was achieved. Seed treatments with SDHI's + triticonazole have been shown to reduce fungal DNA in seed and germinated plants (Clemente et al. 2014). This development, combined with the capacity to quantify $R$. collo-cygni infection levels in seed, opens new opportunities for disease control (Pereyra et al. 2014) but will require further study and careful stewardship of the SDHI fungicides.

RLS control has to be considered in the wider context of disease control on barley crops and it remains important for growers to integrate the requirements for RLS control into general disease management strategies (Hess et al. 2007, 2014). Fungicides are generally applied before symptom expression; therefore, risk forecast management tools are currently being developed and evaluated (Havis et al. 2013). This model relies on quantifying RLS severity risk based on environmental conditions in the crop at stem extension (ZGS 31), well before the optimum fungicide application date.

The rapid rise of RLS during the past 10 years together with the breakdown of fungicide efficacy of certain compounds demonstrate the high adaptive potential of $R$. collo-cygni, the contribution of management practices (in particular, the neglected resistance management), and the continued uncertainty surrounding epidemiological knowledge.

\section{POPULATION GENETICS OF THE FUNGUS}

As a recently established pathogen of barley, there is limited information available on the genetic diversity and population genetics of $R$. collo-cygni. To date, two studies using the amplified fragment length polymorphism technique have examined the level of genetic diversity and population structure of $R$. collo-cygni from Northern

TABLE 3. Testing of different spray strategies to reduce Ramularia leaf spot symptoms in Uruguay ${ }^{x}$

\begin{tabular}{lcc}
\hline Fungicide program & & \\
\hline Untreated & AUDPC & Yield $^{\mathrm{z}}\left(\mathrm{t} \mathrm{h}^{-1}\right)$ \\
ZGS 47 only & $2,025 \mathrm{a}$ & 3.875 \\
ZGS 33 only & $1,229 \mathrm{~b}$ & 4.016 \\
ZGS 38 only & $812 \mathrm{bcd}$ & 4.230 \\
ZGS 33 + GS 38 & $640 \mathrm{bcd}$ & 4.268 \\
ZGS 33 + GS 47 & $607 \mathrm{~d}$ & 4.901 \\
ZGS 38 + GS 47 & $493 \mathrm{~cd}$ & 4.547 \\
ZGS 33 + GS 38 + ZGS47 & $578 \mathrm{~d}$ & 4.952 \\
$F$ value & $427 \mathrm{~cd}$ & 4.625 \\
\hline
\end{tabular}

${ }^{\mathrm{x}}$ Trials were taken to yield (Pereyra et al. 2014); NS = not significant.

y Izopyrazam + azoxystrobin (0.4 liters/ha); ZGS = Zadoks growth stage.

${ }^{\mathrm{z}}$ AUDPC $=$ area under the disease progress curve. Values with the same letter are not significantly different at $P=0.05$ by Tukey's honest significant difference test.

TABLE 2. Development of fungicides with activity on Ramularia leaf spot (RLS) and abiotic spotting (physiological leaf spot [PLS]) as a proportion of fungicides registered for disease control in barley ${ }^{y}$

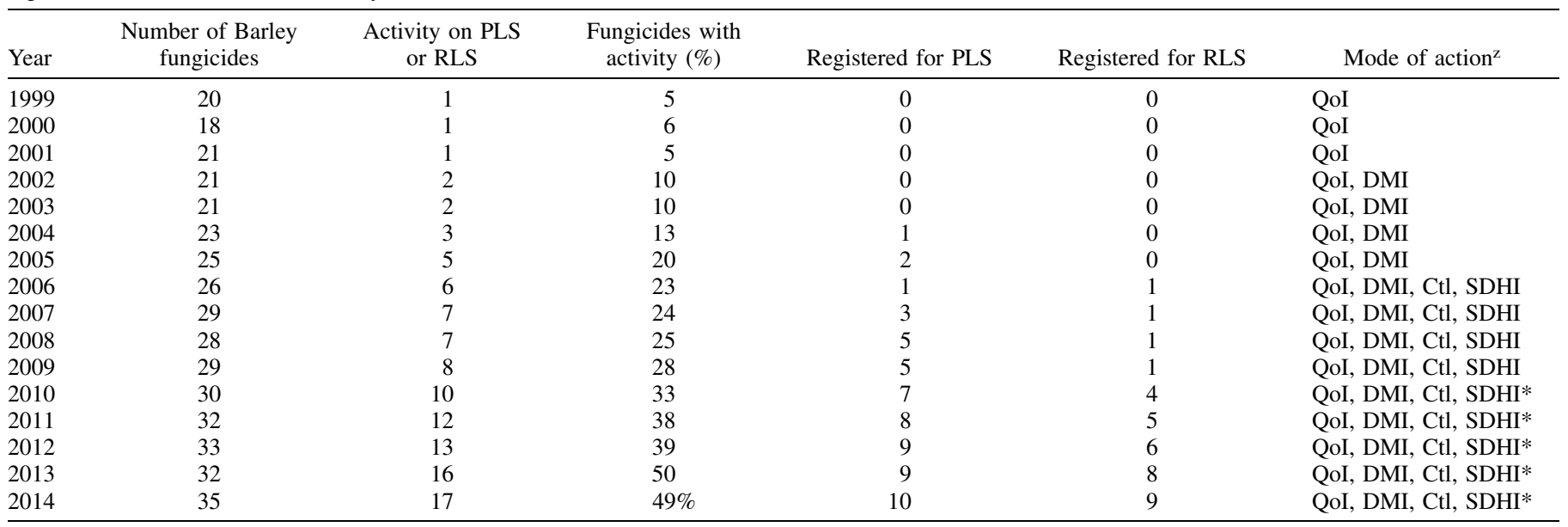

${ }^{y}$ Data provided by Stephan Weigand, Bavarian State Research Center for Agriculture, Freising, Germany.

${ }^{\mathrm{z}} \mathrm{QoI}=$ quinone outside inhibitor, $\mathrm{DMI}=$ demethylation inhibitor, $\mathrm{Ctl}=$ chlorothalonil, $\mathrm{SDHI}=$ succinate dehydrogenase inhibitor, and $\mathrm{SDHI} *=$ new generation of SDHI (bixafen, fluxapyroxad, and isopyrazam). 
(Hjortshøj et al. 2013) and Central (Leisova-Svobodova et al. 2012) Europe. Hjortshøj et al. (2013) compared field populations of $R$. collo-cygni from Scotland and Denmark and revealed high levels of genetic diversity at both locations. This finding was supported by the recent analysis of isolates from Germany, Switzerland, the Czech Republic, and the Slovak Republic (Leisova-Svobodova et al. 2012). Analysis of the genetic structure of $R$. collo-cygni populations using simple-sequence repeat markers demonstrated that the pathogen is highly diverse, is likely to undergo sexual reproduction over the growing season, and has a potential for extensive spore dispersal across the field (Piotrowska 2014). Thus, $R$. collo-cygni has a high evolutionary potential and could adapt to different control measures relatively quickly. Sequence analysis of four $R$. collo-cygni housekeeping genes (glyceraldehyde 3-phosphate dehydrogenase, $\beta$-tubulin, E2 ubiquitin-conjugating protein, and a thioesterase family protein) was used to further address the genetic diversity in $R$. collo-cygni isolates. Sequences were amplified from a selection of geographically distinct $R$. collo-cygni isolates from Scotland (seven isolates), Germany (five isolates), Denmark (two isolates), Russia (one isolate), and New Zealand (one isolate) as well as isolates from hosts other than barley, including oat, Tritordeum, and wheat. Analysis of the sequence data indicated substantial genetic diversity between the isolates (Table 4) (M. Hess, A. Tellier, and H. Shgyer, unpublished), supporting the data of Hjortshøj et al. (2013) and Leisova-Svobodova et al. (2012). Due to the high degree of conservation typically observed with housekeeping genes because their critical role in basic cell maintenance (Watson et al. 1965), these genes were under strong purifying selection, as indicated by the strongly negative values of Tajima's D (Tajima 1989). In addition, because $R$. collo-cygni has recently emerged as a newly important pathogen (Table 1), the negative Tajima's D value observed for the housekeeping genes (Table 4) could partly be explained by a population size expansion. Populations can exhibit characteristic genetic signatures associated with their demographic histories (Cornuet and Luikart 1996; Wakeley 2008). Detecting a history of demographic expansion might help to explain the recent emergence of $R$. collo-cygni; therefore, detailed examination of nonhousekeeping genes is required to evaluate the true genetic diversity of this fungus. Alternatively, because R. collo-cygni has recently emerged as a newly important pathogen (Table1), the negative Tajima's D value observed for the housekeeping genes (Table 4) could be explained by a possible role of a population size expansion. Populations can exhibit characteristic genetic signatures associated with their demographic histories (Cornuet and Luikart 1996; Garza and Williamson 2001; Luikart et al. 1998). Detecting a history of demographic expansion might help explain the recent emergence of $R$. collo-cygni. Detailed examination of nonhousekeeping genes is required to evaluate the true genetic diversity of this fungus. Projects are underway to sequence the genomes of $R$. collo-cygni isolates from multiple geographic locations and nonbarley hosts to provide valuable insights into the genetic diversity of this organism and to address how this diversity has influenced the evolution of the fungus.
The absence of distinct geographical population profiles suggests that seed-borne dispersal of $R$. collo-cygni has probably played an important role in the long-distance spread of RLS. It is worth noting that many of the Southern hemisphere countries which have reported RLS are also used by breeding companies for "secondseason" trials (P. Werner, personal communication). The high level of genotypic diversity in $R$. collo-cygni could point to sexual recombination within fungal populations (Hjortshøj et al. 2013) although, because clonal lineages have been reported, a mixed mode of reproduction including both clonal and sexual is likely (Leisova-Svobodova et al. 2012). Despite the evidence indicating that $R$. collo-cygni undergoes sexual recombination, the sexual stage of the fungus is yet to be identified (Salamati and Reitan 2006). Confirmation of the sexual stage of the fungus and the mating type system will provide further insights into the population dynamics of $R$. collo-cygni.

\section{GENETICS AND THE ROLE OF PLANT BREEDING TO CONTROL DISEASE}

Shortly after RLS became an economically significant disease of barley in many temperate regions in the late 1990s, it was recognized that cultivars varied in susceptibility to it. In New Zealand in 1999, barley trials were heavily attacked by $R$. collocygni and two cultivars were especially susceptible to the disease (Sheridan 2000). There is still a demand for improved resistance in varieties. In Uruguay in 2013, $100 \%$ of the varieties sown were susceptible or at best moderately susceptible to RLS (Pereyra et al. 2014). The potential for resistant cultivars to contribute to controlling RLS in Denmark was recognized (Pinnschmidt and Hovmøller 2003) and variation in disease levels was identified in a large panel of spring and winter cultivars (Pinnschmidt and Hovmøller 2004; Pinnschmidt et al. 2006a). Significant variation in susceptibility between cultivars and breeding lines was also detected in Lithuania (Leistrumaite and Liatukas 2006), the United Kingdom (Oxley et al. 2008), and Slovakia (Gubiš et al. 2008). Significant differences in the RLS susceptibility of winter barley cultivars was found in the Czech Republic (Mařík et al. 2011) but only limited variation between spring cultivars (Matušinsky et al. 2013). In all of these cases, there was quantitative variation in resistance with no clear division between resistant and susceptible cultivars, suggesting that RLS resistance is generally a quantitative trait.

At an early stage, a correlation between the presence of mlo mildew resistance and susceptibility of barley to RLS was noticed. The Mlo gene in barley is required for susceptibility to powdery mildew (Blumeria graminis); therefore, nonfunctional ( $m l o$ ) alleles confer recessively inherited resistance to this disease. The mlo- 11 allele especially and also mlo-9 have been used widely in spring barley breeding in Europe but not in winter barley (Jørgensen 1992). In trials of 75 barley cultivars in Denmark, all but 1 of the 13 most susceptible to RLS had mlo while all of the 18 least susceptible lines lacked mlo (Pinnschmidt et al. 2006a). A potential difficulty with

TABLE 4. Estimates of gene diversity of four Ramularia collo-cygni housekeeping genes ${ }^{\mathrm{v}}$

\begin{tabular}{|c|c|c|c|c|c|c|c|c|}
\hline Gene $^{w}$ & $n$ & Watterson $^{\mathrm{x}}$ & Theta-W per gene ${ }^{\mathrm{x}}$ & $\mathrm{R}$ per gene $\mathrm{y}^{\mathrm{y}}$ & Tajima's D & $\begin{array}{l}\text { Tajima's D } \\
\text { coding region }\end{array}$ & $\begin{array}{c}\text { Tajima's D } \\
\text { nonsynonymous }\end{array}$ & $\begin{array}{c}\text { Fu and Li D } \\
\text { with outgroup }\end{array}$ \\
\hline GAPDH & 21 & 17 & 4.725 & 17.900 & $-2.648 * * *$ & $-2.724 * * *$ & $-2.705 * * *$ & -1.282 \\
\hline$\beta$ Tub & 18 & 19 & 5.524 & 13.400 & $-2.498 * * *$ & $-2.549 * * *$ & $-2.580 * * *$ & 0.024 \\
\hline $\mathrm{E} 2 \mathrm{Ub}$ & 21 & 18 & 5.003 & 0.001 & $-2.651 * * *$ & $-2.558 * * *$ & $-2.589 * * *$ & $-3.047 * *$ \\
\hline Thios & 21 & 11 & 3.057 & 0.001 & $-2.302 * *$ & $\ldots$ & $\ldots$ & $-3.258 * *$ \\
\hline Mean & $\ldots$ & 16.25 & 4.577 & 7.826 & -2.611 & -2.611 & -2.625 & -1.891 \\
\hline
\end{tabular}

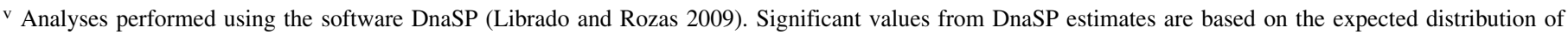
D for a neutral model of evolution (Tajima 1989): ** and *** indicate $P<0.01$ and 0.001 , respectively.

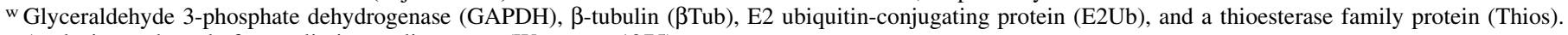

$x$ Analysis conducted after preliminary alignments (Watterson 1975).

y Scaled population recombination rate $(\mathrm{R})$ per gene.

z Outgroup: Mycosphaerella graminicola strain IPO323. 
making conclusions about the effect of $m l o$ from these trials was that other factors, including other diseases, might have affected RLS levels. In an analysis of RLS scores from a large number of naturally infected trials in Denmark, two-thirds of the variation between trial plots was explained by extraneous factors, including cultivars' susceptibility to other diseases, while variation between cultivars in susceptibility to RLS accounted for the remaining one-third of variation. Once other factors were removed, there was a strong association between the presence of $m l o$ and high susceptibility to RLS resulting from natural infection. This result was replicated in inoculated trials (Pinnschmidt and Sindberg 2009).

A series of genetic experiments using stocks which varied in alleles of the Mlo gene largely supported the conclusion of the field trials described above but also raised questions about the mechanism by which mlo mildew resistance affects RLS. Much of this work used near-isogenic lines (NILs), in which different mlo alleles had been bred into a susceptible background, replacing the wild-type $\mathrm{Mlo}^{+}$allele. First, in field trials in Scotland and Ireland in which overall levels of RLS were fairly low, mlo alleles were associated with a moderate decrease in symptoms, in contrast to the results of the Danish field trials (Makepeace et al. 2007). A separate study indicated that high light levels before inoculation were conducive to the formation of leaf-spotting symptoms (Makepeace et al. 2008); therefore, another series of experiments was conducted on NILs with either $\mathrm{Mlo}^{+}$(mildew-susceptible wild-type) or mlo-5 (mildew-resistant) in controlled environment chambers to examine the relationship between RLS, mlo-5, and environmental stress. The highest two levels of light intensity before inoculation increased RLS symptoms on both $\mathrm{Mlo}^{+}$and mlo-5 lines; however, the increase was much greater with mlo-5. With the lowest preinoculation light level, symptoms were lower overall and did not differ significantly between $\mathrm{Mlo}^{+}$and mlo-5 lines (Brown and Makepeace 2009). In similar environmental conditions, mlo-5 was associated not only with increased RLS but also with a larger amount of the $R$. collocygni fungus within the leaf (McGrann et al. 2014). Further support for the effect of $m l o$ alleles on susceptibility to RLS came from field trials of a doubled-haploid population produced from a cross between Braemar, a highly RLS-susceptible mlo- 11 cultivar, and Power, a RLS-resistant one with $\mathrm{Mlo}^{+}$. Gene $\mathrm{mlo}-11$ was associated with increased susceptibility to RLS across the series of trials as a whole but the effect was considerably stronger in Bavaria, where half of the trials were located, than in the other trials in Scotland or in tests of seedlings. In a quantitative trait locus (QTL) analysis, the only significant QTL was at the Mlo locus, which accounted for up to $37 \%$ of genetic variation at the site with the greatest difference (McGrann et al. 2014).

The overall conclusion from the work on mlo is that the mildewresistance allele is very likely to contribute to the susceptibility of spring barley cultivars to RLS but the strength of this effect varies with the environment, location, and genetic background. The fact that there is significant variation in RLS susceptibility between cultivars (Pinnschmidt et al. 2006b) and other lines (McGrann et al. 2014) with mlo indicates that there is the potential for breeders to mitigate this undesirable trade-off of by selecting spring barley cultivars with mlo mildew resistance and moderately good resistant to RLS.

Breeding for RLS resistance continues to rely almost entirely on phenotypic selection. The existence of variation between cultivars in susceptibility not affected by mlo indicates that there must be other genes controlling this trait. Given that RLS scores on different cultivars appear to have a continuous distribution, it is most likely that, mlo apart, resistance is polygenic, with many genes dispersed throughout the barley genome, each having a minor impact on disease. Although the individual effect of each gene may be small, sustained selection for lower disease levels should produce cultivars bearing gene combinations with a large cumulative effect. In experiments on barley NILs, ror mutants, which partially restore susceptibility to mildew in mlo plants, alleviated RLS symptoms in mlo lines; however, they did not reduce the amount of $R$. collo-cygni fungus in the leaf (McGrann et al. 2014). This indicates that resistance to the fungus and resistance to symptom formation are at least partly under separate genetic control. Both may be relevant to barley production, the former to reduce inoculum pressure and the latter to maintain green leaf area. The impact of environmental variation on selection for resistance is not yet well understood. Not only has the effect of mlo on RLS varied between trials (see above) but also there is other significant genotype-environment interaction in the relative susceptibility of barley cultivars and breeding lines in different locations (Hjortshøj 2012; Pinnschmidt and Hovmøller 2004; Pinnschmidt and Sindberg 2009; Pinnschmidt et al. 2006b), which implies that it may be necessary to conduct field trials in several locations. Although a method of inoculating seedlings with R. collo-cygni is available (Makepeace et al. 2008), selection at the seedling stage may not be an adequate replacement for performing field trials. The effect of $m l o$ on RLS was weaker in seedlings of the Power $\times$ Braemar population than in some field trials (McGrann et al. 2014) whereas 'Decanter', which was moderately resistant in the field (Oxley et al. 2008), was susceptible as a seedling (Makepeace et al. 2008).

The most productive approach to breeding for RLS resistance at present is probably to use diverse germplasm as sources of partial resistance, to perform trials on populations at locations with high levels of natural infection by $R$. collo-cygni, and to select cultivars which have better resistance to RLS than their parents while combining broad-spectrum resistance to all commercially significant diseases with other desirable traits. This approach has led to improvements in resistance to many other diseases of arable crops. Resistance to RLS is now included in the official trial system in several countries, such as the HGCA Recommended List in the United Kingdom (http://www.hgca.com/varieties/hgca-recommendedlists.aspx). Thus, farmers have access to objective information about cultivars which are less susceptible to RLS and breeders have an incentive to produce them.

\section{CONCLUSIONS}

Recognition of RLS across the world is continuing and has been followed by reports of recent epidemics in both the northern and southern hemisphere. Despite the developments in RLS research, there are still a number of outstanding questions which require the attention of the community to improve understanding of $R$. collocygni biology and RLS control. The major source of inoculum in the field is still a subject of debate. There is strong evidence implicating seed-borne transmission as an important inoculum source but the specific role that spore transmission plays is still unclear. The wide distribution of $R$. collo-cygni suggests a role for seed as an important factor in long-range transport of the fungus, and the small spore size and its wind-borne nature suggest that this, along with seed movement, may be involved in local dispersal. Further testing of spore movement in different growing conditions could indicate what part spore-borne transmission plays in RLS epidemiology. The classification of the trophic lifestyle of $R$. collo-cygni is still under debate. Many consider the fungus a hemibiotroph with an extended latent phase but there is an increasing amount of evidence pointing toward an endophytic relationship between $R$. collo-cygni and barley, with an eventual shift toward necrotrophy, depending on plant development. As the genetics of the fungus and the host begin to be investigated, there is the potential to gain further insights into the relationship between the fungus and host, the evolution of the fungus, its potential host range, and the opportunities for disease control. Most importantly, research efforts must be focused on using advances in disease epidemiology, chemical control, and breeding for disease resistance, thus exploiting advances in both pathogen genomics and host genetics, to work toward alleviating the economic loss from symptom development. In summary, the rise of the fungus to the position of a major pathogen in only 30 years and 
increasing detection and recognition on new hosts and continents suggests that further developments lie ahead.

\section{ACKNOWLEDGMENTS}

We thank all of the contributors who offered unpublished data for the review and S. Thomson (Scotlands Rural College [SRUC]) for the distribution map.

\section{LITERATURE CITED}

Afanasenko, O. S., Havis, N. D., Bespalova, L. A., Ablova, I. B., and Marienko, V. I. 2012. Ramularia leaf spot is a new barley disease in Russia. Plant Prot. Quarantine 1:11-13.

Bartlett, D. W., Clough, J. M., Godwin, J. R., Hall, A. A., Hamer, M., and Parr-Dobrzanski, B. 2002. The strobilurin fungicides. Pest Manag. Sci. 58: 649-662.

Brown, J. K. M., and Makepeace, J. C. 2009. The effect of genetic variation in barley on responses to Ramularia collo-cygni. Asp. Appl. Biol. 92:43-47.

Carmona, M. A., Scandiani, M. M., Formento, A. N., and Luque, A. 2013. Epidemias de Ramularia collo-cygni, organismo causal del salpicado necrótico de la cebada. Pages 44-47 in: Campaña 2012-2013 Revista Cultivos Invernales en SD de Aapresid. Online publication. Cultivos Invernales, AAPRESID. www.aapresid.org.ar

Cavara, F. 1893. Über einige parasitische Pilze auf dem Getreide. Z. Pflanzenkrankheit 3:16-26.

Clemente, G., Quintana, S., Aguirre, N., Rosso, A., Cordi, N., and Havis, N. D. 2014. State of art of Ramularia collo-cygni (leaf spot of barley) in Argentina and detection and quantification of $R$. collo-cygni by real-time PCR in barley plantlets and seeds treated with fungicide. In: Proc. 11th Conf. Eur. Found. Plant Pathol. Krakow, Poland.

Cornuet, J.-M., and Luikart, G. 1996. Description and power analysis of two tests for detecting recent population bottlenecks from allele frequency data. Genetics 144:2001-2014.

Erreguerena, I. A., Quiroz, F. J., Montoya, M. R. A., Maringolo, C. A., Lazzaro, N., and Giménez, F. 2014. Ventana de protección para el control químico de Ramularia collo-cygni y Rhynchosporium secalis en cebada en el sudeste bonaerense. In: Resúmenes III Cong. Argentino Fitopatol. San Miguel de Tucumán, Argentina.

Formayer, H., Huss, H., and Kromb-Kolb, H. 2004. Influence of climatic factors on the formation of symptoms of Ramularia collo-cygni. Pages 329-330 in: Proc. Second Int. Workshop Barley Leaf Blights. A. H. Yahyaoui, L. Brader, A. Tekauz, H. Wallwork, and B. Steffenson, eds. Edmonton, Canada.

Fountaine, J., and Fraaije, B. A. 2009. Development of QoI resistant alleles in populations of Ramularia collo-cygni. Asp. Appl. Biol. 92:123-126.

Fraaije, B. A., Cools, H. J., Fountaine, J., Lovell, D. J., Motteram, J., West, J. S., and Lucas, J. A. 2005. Role of ascospores in further spread of QoIresistant cytochrome b alleles (G143A) in field populations of Mycosphaerella graminicola. Phytopathology 95:933-941.

FRAC. 2014. Mode of Action of Fungicides. Online publication. http://www. frac.info/publications/downloads

Frei, P., and Gindrat, D. 2000. Le champignon Ramularia collo-cygni provoque une forme de grillures sur les feuilles d'orge d'automne et de graminées adventices. Rev. Suisse Agric. 32:229-233.

Frei, P., Gindro, K., Richter, H., and Schürch, S. 2007. Direct-PCR detection and epidemiology of Ramularia collo-cygni associated with barley necrotic leaf spots. J. Phytopathol. 155:281-288.

Garza, J. C., and Williamson, E. G. 2001. Detection of reduction in population size using data from microsatellite loci. Mol. Ecol. 10:305-318.

Gubiš, J., Hudcovicova, M., and Klcova, L. 2008. First report of Ramularia collo-cygni in Slovakia. J. Plant Pathol. 90:149.

Havis, N. D., Burnett, F., Hughes, G., and Yoxall, T. 2013. Development of a risk forecast model for the barley disease Ramularia leaf spot. In: Proc. Future IPM Eur. Conf. Riva del Garda, Italy.

Havis, N. D., Gorniak, K., Carmona, M. A., Formento, A. N., Luque, A. G., and Scandiani, M. M. 2014a. First molecular detection of Ramularia leaf spot (Ramularia collo-cygni) in seeds and leaves of barley in Argentina. Plant Dis. 98:277.

Havis, N. D., Kaczmarek, M., and Fountaine, J. M. 2014b. Ramularia collocygni-A rapidly developing problem. Pages 95-100 in: Proc. Crop Prot. North. Britain. Dundee, Scotland.

Havis, N. D., Oxley, S. J. P., Piper, S. R., and Langrell, S. R. H. 2006. Rapid nested PCR-based detection of Ramularia collo-cygni direct from barley. FEMS Microbiol. Lett. 256:217-223.

Havis, N. D., Nyman, M., and Oxley, S. J. P. 2010. Potential of seed treatment to control Ramularia- collo-cygni in barley. Pages 97-102 in: Proc. Crop Prot. North. Britain. Dundee, Scotland.
Havis, N. D., Nyman, M., and Oxley, S. J. P. 2014c. Evidence for seed transmission and symptomless growth of Ramularia collo-cygni in barley (Hordeum vulgare). Plant Pathol. 63:929-936.

Havis, N. D., Oxley, S. J. P., Burnett, F., and Hughes, G. 2012. Epidemiology of Ramularia collo-cygni. Pages 119-124 in: Proc. Crop Prot. North. Britain. Dundee, Scotland.

Havis, N. D., Paterson, L., Taylor, J. M. G., and Walters, D. R. 2009a. Use of Resistance Elicitors to control Ramularia collo-cygni in spring barley. Asp. Appl. Biol. 92:127-132.

Havis, N. D., Taylor, J. M. G., Nyman, M., and Oxley, S. J. P. 2009b. Epidemiology of Ramularia collo-cygni. Asp. Appl. Biol. 92:1-7.

Hess, M., Gastl, M., Weigand, S., Henkelmann, G., and Rychlik, M. 2011. Influence of crop health and fungal contamination of spring barley on mycotoxin content and malting quality. In: Proc. 33rd Eur. Brew. Conv. Cong. Glasgow, Scotland.

Hess, M., Habecker, R., Kick, M., Martin, M., and Hausladen, H. 2007. Occurrence of the late leaf spot complex of barley and its consequences on optimized disease control. Gesunde Pflanzen 59:47-54.

Hess, M., Sghyer, H., Hausladen, H., and Weigand, S. 2014 Studying the epidemiology of Ramularia collo-cygni for the improvement of an Integrated Pest Management system in a changing climate. In: Proc. 11th Conf. Eur. Found. Plant Pathol. Krakow, Poland.

Hess, M., Weigand, S., and Hausladen, H. 2009. Studying the epidemics of Ramularia collo-cygni in Germany and Austria with different diagnostic tools; development of field diagnostics and implications for integrated disease control. Asp. Appl. Biol. 92:9-16.

HGCA. 2014. Fungicide performance in barley. Online publication. http:// www.hgca.com/crop-management/disease-management/fungicide-performance/ fungicide-performance-in-barley.aspx

Hjortshøj, R. L. 2012. Improving resistance to Ramularia leaf spot in barley. Ph.D. thesis, Aarhus University, Denmark.

Hjortshøj, R. L., Ravnshoj, A. R., Nyman, M., Orabi, J., Backes, G., Pinnschmidt, H., Havis, N. D., Stougaard, J., and Stukenbrock, E. H. 2013. High levels of genetic and genotypic diversity in field populations of the barley pathogen Ramularia collo-cygni. Eur. J. Plant Pathol. 136:51-60.

Huss, H. 2002. The biology of Ramularia collo-cygni. Pages 321-328 in: Proc. Second Int. Workshop Barley Leaf Blights. Aleppo, Syria.

Jørgensen, J. H. 1992. Discovery, characterization and exploitation of mlo powdery mildew resistance in barley. Euphytica 63:141-152.

Kaczmarek, M., Fountaine, J. M., Newton, A. C., Read, N. D., and Havis, N. D. 2013. The life history of Ramularia collo-cygni. In: 27th Fungal Genet. Conference, Asilomar, CA. Online publication. www.fgsc.net/ 27thFGC/FungalProgramBook2013.pdf

Khier, M., Carmona, M., Sachs, E., Delhey, R., Frayssinet, S., and Barreto, D. 2002. Salpicado necrótico, nueva enfermedad de la cebada en Argentina causada por Ramularia collo-cygni. Resúmenes XI Jornadas Fitosanitarias Argentinas. 47. Cordoba, Argentina.

Koric, B., Tomic, Z., Simala, M., and Milek, M. 2009. Ramularia leaf spot on barley in the Republic of Croatia. Zbornik predavanj in referatov 9. slovenskega posvetovanja o varstvu rastlin $\mathrm{z}$ mednarodno udeležbo. Nova Gorica, Slovenia.

Leisova-Svobodova, L., Matusinsky, P., and Kucera, L. 2012. Variability of the Ramularia collo-cygni population in Central Europe. J. Phytopathol. 160: 701-709.

Leistrumaite, A., and Liatukas, Z. 2006. Resistance of spring barley cultivars to the new disease Ramularia leaf spot, caused by Ramularia collo-cygni. Agron. Res. 4:251-255.

Librado, P., and Rozas, J. 2009. DnaSP v5. A software for comprehensive analysis of DNA polymorphism data. Bioinformatics 25:1451-1452.

Luikart, G., Allendorf, F. W., Cornuet, J.-M., and Sherwin, W. B. 1998. Distortion in allele frequency distributions provides a test for recent population bottlenecks. J. Hered. 89:238-247.

Makepeace, J. C., Havis, N. D., Burke, J. I., Oxley, S. J. P., and Brown, J. K. M. 2008. A method of inoculating barley seedlings with Ramularia collo-cygni. Plant Pathol. 57:991-999.

Makepeace, J. C., Oxley, S. J. P., Havis, N. D., Hackett, R., Burke, J. I., and Brown, J. K. M. 2007. Associations between fungal and abiotic leaf spotting and the presence of mlo alleles in barley. Plant Pathol. 56:934-942.

Mařík, P., Snejdar, Z., and Matusinsky, P. 2011. Expression of resistance to Ramularia leaf spot in winter barely cultivars grown in conditions of the Czech Republic. Czech J. Genet. Plant Breed. 47:37-40.

Matušinsky, P., Hanusová, M., Stemberková, L., Mařík, P., Minaříková, V., Tvarůžek, L., Langer, I., and Spitzer, T. 2013. Response of spring barley cultivars to Ramularia leaf spot in conditions of the Czech Republic. Cereal Res. Commun. 41:126-132.

Matusinsky, P., Leisova-Svobodova, L., Gubiš, J., Hudcovicova, M., Klcova, L., Gubisova, M., Marik, P., Tvaruzek, L., and Minarikova, V. 2011. Impact of the seed-borne stage of Ramularia collo-cygni in barley seed. J. Plant Pathol. 93:679-689. 
Matusinsky, P., Leisova-Svobodova, L., Marik, P., Tvaruzek, L., Stemberkova, L., Hanusova, M., Minarikova, V., Vysohlidova, M., and Spitzer, T. 2010. Frequency of a mutant allele of cytochrome b conferring resistance to QoI fungicides in the Czech population of Ramularia collo-cygni. J. Plant Dis. Prot. 117:248-252.

McGrann, G. R. D., Stavrinides, A., Russell, J., Corbitt, M. M., Booth, A., Chartrain, L., Thomas, W. T. B., and Brown, J. K. M. 2014. A trade-off between mlo resistance to powdery mildew and increased susceptibility of barley to a newly important disease, Ramularia leaf spot. J. Exp. Bot. 65: 1025-1037.

Miethbauer, S., Heiser, I., and Liebermann, B. 2003. The phytopathogenic fungus Ramularia collo-cygni produces biologically active rubellins on infected barley leaves. J. Phytopathol. 151:665-668.

Newton, A. C., Fitt, B. D., Atkins, S. D., Walters, D. R., and Daniell, T. J. 2010. Pathogenesis, parasitism and mutualism in the trophic space of microbe-plant interactions. Trends Microbiol. 18:365-373.

Nyman, M., Havis, N. D., and Oxley, S. J. P. 2009. Importance of seed-borne infection of Ramularia collo-cygni. Asp. Appl. Biol. 92:91-96.

Oxley, S. J. P., and Havis, N. D. 2009. Understanding Ramularia collo-cygni in the past, present and future. Asp. Appl. Biol. 92:141-146.

Oxley, S. J. P., and Havis, N. D. 2010. Managing Ramularia collo-cygni through varietal resistance, seed health and forecasting. HGCA Project Rep. 463. Online publication. www.hgca.com/media/267653/pr463.pdf

Oxley, S. J. P., Havis, N. D., Brown, J. K. M., Makepeace, J. C., and Fountaine, J. 2008. Impact and interactions of Ramularia collo-cygni and oxidative stress in barley. Project Rep. 431. Online publication. www.hgca.com/ media/269134/pr431.pdf

Peraldi, A., Griffe, L. L., Burt, C., McGrann, G. R. D., and Nicholson, P. 2014. Brachypodium distachyon exhibits compatible interactions with Oculimacula spp. and Ramularia collo-cygni, providing the first pathosystem model to study eyespot and Ramularia leaf spot diseases. Plant Pathol. 63:554-562.

Pereyra, S. 2013. Herramientas disponibles para el manejo de dos enfermedades relevantes de la pasada zafra: Fusariosis de la espiga en trigo y Ramularia en cebada. Actividades Difusion INIA 720:33-41.

Pereyra, S. A., Viera, J. P., and Havis, N. 2014. Managing Ramularia leaf spot of barley in Uruguay. In: Proc. APS-CPS Joint Meet. Minneapolis, MN. Poster-297.

Pinnschmidt, H. O., and Hovmøller, M. S. 2003. Ramularia, a new disease of barley-A review of present knowledge. DJF Rapport 89:313-321.

Pinnschmidt, H. O., and Hovmøller, M. S. 2004. Resistance against net blotch, scald and Ramularia of barley. DJF Rapport 98:61-71.

Pinnschmidt, H. O., and Jørgensen, L. N. 2009. Yield effects of Ramularia leaf spot on spring barley, pp. 57-66. Asp. Appl. Biol. 92:57-66.

Pinnschmidt, H. O., and Sindberg, S. A. 2009. Assessing Ramularia leaf spot resistance of spring barley cultivars in the presence of other diseases. Asp. Appl. Biol. 92:71-80.

Pinnschmidt, H. O., Sindberg, S. A., and Willas, J. 2006a. Expression of resistance of barley varieties to Ramularia leaf spot and the status of the disease in Denmark. Pages 85-93 in: Proc. First Eur. Ramularia Workshop. Gottingen, Germany.

Pinnschmidt, H. O., Sindberg, S. A., and Willas, J. 2006b. Resistant barley varieties may facilitate control of Ramularia leaf spot. DARCOFenews, November 2006b. Online publication. http://www.darcof.dk/enews/newsmail/ november_2006/rls.html

Piotrowska, M. 2014. Evaluating the risk of fungicide resistance evolution to succinate dehydrogenase inhibitors in Ramularia collo-cygni. Ph.D. thesis, University of Edinburgh.
Russell, P. E. 2009. Fungicide resistance action committee (FRAC): A resistance activity update. Outlooks Pest Manage. 20:122-125.

Sachs, E. 2006. The history of research into Ramularia leaf spot on barley. Pages 9-15 in: Proc. First Eur. Ramularia Workshop. Gottingen, Germany.

Salamati, S., and Reitan, L. 2006. Ramularia collo-cygni on spring barley, an overview of its biology and epidemiology. Pages 19-35 in: Proc. First Eur. Ramularia Workshop. Gottingen, Germany.

Schützendübel, A., Stadler, M., Wallner, D., and von Tiedemann, A. 2008. A hypothesis on physiological alterations during plant ontogenesis governing susceptibility of winter barley to Ramularia leaf spot. Plant Pathol. 57: 518-526.

Sheridan, J. E. 2000. Cereal diseases 1999-2000 (including pea diseases and gooseberry mildew) disease survey and disease control in the Wairarapa, New Zealand. Mycol. Plant Pathol. Rep. 37. Victoria University of Wellington, New Zealand.

Sooväli, P., Tikhonova, M., and Matušinsky, P. 2014. First report of Ramularia leaf spot caused by Ramularia collo-cygni on leaves and seeds of barley in Estonia. Plant Dis. 98:997.

Stewart, S. 2001. Manchado necrótico en cebada. Actividades Difusion INIA 254:47-49.

Sutton, B., and Waller, J. 1988. Taxonomy of Ophicladium hordei causing leaf lesions on Triticale and other Graminutesae. Trans. Br. Mycol. Soc. 90: 55-61.

Tajima, F. 1989. Statistical method for testing the neutral mutation hypothesis by DNA polymorphism. Genetics 123:585-595.

Taylor, J. M. G., Paterson, L., and Havis, N. D. 2010. A quantitative real-time PCR assay for the detection of Ramularia collo-cygni from barley (Hordeum vulgare). Lett. Appl. Microbiol. 50:493-499.

Thirugnanasambandam, A., Wright, K. M., Havis, N. D., Whisson, S. C., and Newton, A. C. 2011. Agrobacterium-mediated transformation of the barley pathogen Ramularia collo-cygni with fluorescent marker tags and live tissue imaging of infection development. Plant Pathol. 60:929-37.

Toscano-Underwood, C., West, J. S., Fitt, B. D. L., Todd, A. D., and Jędryczka, M. 2001. Development of phoma lesions on oilseed rape leaves inoculated with ascospores of A-group or B-group Leptosphaeria maculans (stem canker) at different temperatures and wetness durations. Plant Pathol. 50:28-41.

Wakeley, J. 2008. Coalescent Theory: An Introduction. Roberts \& Company Publishers, Greenwood Village, CO.

Walters, D. R., Avrova, A., Bingham, I. J., Burnett, F. J., Fountaine, J., Havis, N. D., Hoad, S. P., Hughes, G., Looseley, M., Oxley, S. J. P., Renwick, A., Topp, C. F. E., and Newton, A. C. 2012. Control of foliar diseases in barley: Towards an integrated approach. Eur. J. Plant Pathol. 133:33-73.

Walters, D. R., Havis, N. D., and Oxley, S. J. P. 2008. Ramularia collo-cygni: The biology of an emerging pathogen of barley. FEMS Microbiol. Lett. 279:1-7.

Watson, J. D., Hopkins, N. H., Roberts, J. W., Steitz, J. A., and Weiner, A. M. 1965. Molecular Biology of the Gene, Vol. 1. Benjamin/Cummings, Menlo Park, CA.

Watterson, G. A. 1975. On the number of segregating sites in genetical models without recombination. Theor. Popul. Biol. 7:256-276.

Zadoks, J. C., Chang, T. T., and Konzak, C. F. 1974. A decimal code for the growth stages of cereals. Weed Res. 14:415-421.

Zamani-Noor, N. 2011. Studies on Ramularia leaf spots on barley-Resistance phenotyping, epidemiology and pathogenicity. Ph.D. thesis, Georg-AugustUniversity Göttingen, Germany.

Zamani-Noor, N., Schützendübel, A., Koopmann, B., and von Tiedemann, A. 2009. Epidemiology and pathogenicity of Ramularia collo-cygni associated with barley necrotic leaf spot disease. Asp. Appl. Biol. 92:41-42. 